\title{
STRATEGI PENILAIAN OBJEK WISATA CENGKEH AFO SEBAGAI UPAYA PENGUATAN SEKTOR PARIWISATA DI TERNATE
}

\author{
Sunaidin Ode Mulae, S.S.,M.Hum \\ Dosen Usaha Perjalanan Wisata Fakultas Ilmu Budaya Universitas Khairun \\ Email: sunaidin65@gmail.com \\ Rusli M. Said, S.S.,M.Hum \\ Dosen Sastra Sejarah Fakultas Ilmu Budaya Universitas Khairun \\ Email: ruslisaid0383@gmail.com
}

\begin{abstract}
ABSTARK. Penelitian ini bertujuan untuk mengetahui kekuatan dan kelemahan dari faktor internal serta peluang dan ancaman dari faktor eksternal objek wisata cengkeh Afo sebagai tujuan wisata rempah-rempah di Ternate, dan untuk mengetahui strategi pengembangan objek wisata cengkeh Afo sebagai destinasi tujuan wisata rempah-rempah (Spices tourism). Metode yang digunakan dalam penelitian ini adalah penelitian deskriptif (descriptive research) atau eksplanatory terhadap masalah-masalah berupa fakta-fakta saat ini dari suatu populasi. Teknik pengumpulan data pada penelitian menggunakan metode observasi (pengamatan), wawancara (interview), dokumentasi dan kajian pustaka. Hasil yang ditemukan adalah aksesbilitas di cengkeh afo cukup baik, amenitas sangat menunjang, atraksi cukup bagus. Simpulan pada penilaian terhadap objek wisata cengkeh afo berada pada diagram batang yang menunjukan bahwa faktor internal dan ekternal pada objek wisata cengkeh afo dari penilaian 26 responden menemukan sangat variatif yaitu pda responden nomor 1 sampai 26 mempunyai penilaian terhadap objek wisata terendah $14,18 \%$ sampai pada tertinggi $89,55 \%$, atau keseluruhan $867,22 \%$, dalam hal ini menunjukan bahwa potensi objek wisata cengkeh afo dapat dikembang menjadi tujuan wisatawan yang cukup baik.
\end{abstract}

Kata kunci: Penilaian; Strategi; Cengkeh afo

ABSTRACT. This study aims to determine the strengths and weaknesses of internal factors as well as opportunities and threats from the external factors of the clove afo tourism object as a spice tourism destination in Ternate, and to determine the strategy of developing clove afo tourism objects as a spice tourism destination. ). The method used in this research is descriptive research (explanatory) or explanatory to the problems in the form of the current facts of a population. Data collection techniques in research using the method of observation, interviews, documentation and literature. The results found are the accessibility in clove afo is quite good, the amenities are very supportive, the attractions are quite good. Conclusions on the assessment of the clove afo attractions are in the bar diagram showing that internal and external factors on the clove afo attractions from the assessment of 26 respondents found very varied namely respondents pda numbers 1 to 26 had an assessment of the lowest tourist attraction $14.18 \%$ to the the highest $89.55 \%$, or overall $867.22 \%$, in this case shows that the potential of Afo clove attractions can be developed into a pretty good tourist destination.

Keywords: Assessment; Strategy; Clove afo

http://ejournal.unkhair.ac.id/index.php/humano 364 


\section{PENDAHULUAN}

Potensi wisata Ternate terdiri dari wisata budaya, sejarah semisal wisata benteng oranje, kastela, toloko, kalamata, dan kastela merupakan salah satu objek wisata vital dikelompokkan pada objek wisata peninggalan sejarah. Ternate juga memiliki objek wisata alam semisal objek wisata cengkeh afo dan pantai, semisal pantai sulamadaha, dorpedu dan jikomalamo. Ternate juga mempunyai potensi objek wisata alam dan angrowisata yang cukup baik untuk dikembangkan. Namun kondisi rill menunjukan bahwa pemanfaatan objek wisata alam dan agrowisata semisal cengkeh afo belum optimal dikembangkan oleh pihak pemerintah dan pelaku pariwisata karena belum terdatanya secara baik potensi seni dan budaya di area objek sehingga tidak ada informasi awal untuk membuat atraksiatraksi ditempat wisata. Dalam diskursus tersebut perlunya dilakukan identifikasi penilaian atas potensi wisata yang sudah ada sehingga dapat dibuat lebih menarik untuk dikunjungi oleh wisatawan.

Disadari atau tidak akibat langsung yang akan timbul dari pemberian identifikasi penilain melalui penelitian ini adanya daerah basah dan kering yang menyebabkan potensi objek wisata dalam pendapatan tidak sama. Objek wisata kaya akan sumber daya seni-budaya otomatis menjadi daerah basah atau memperoleh manfaat benefit. Sedangkan daerah yang kering sumber daya seni-budaya tidak dapat meningkatkan benefit-nya, karena jika dicermati terdapat beberapa potensi objek wisata yang ada di Ternate merubah paradigma, seperti objek wisata cengkeh Afo di Kelurahan Tongole. Objek Wisata Cengkeh Afo belum terlalu viral diketahui masyarakat kota Ternate.
Penelitian ini merumuskan permasalahan yaitu (1) Apa sajakah kekuatan dan kelemahan serta peluang dan ancaman dalam pengembangan objek wisata cengkeh Afo? Bagaimana strategi pengembangan objek wisata cengkeh $A f o$ sebagai wisata rempah-rempah (Spices tourism)?

\section{TINJAUAN PUSTAKA}

Pariwisata berasal dari bahasa Sansekerta yang terdiri dari dua kata yaitu kata pari dan kata wisata. Kata pari berarti penuh, seluruh, atau semua. Kata wisata berarti perjalanan. Kata pariwisata dapat diartikan perjalanan penuh, mulai berangkat dari suatu tempat, ke satu atau beberapa tempat lain dan singgah kemudian ke tempat wisata (Kuncoro, 2004). Istilah Pariwisata seringkali disepadankan juga dengan istilah tourism, yang secara umum diartikan sebagai suatu kegiatan untuk melakukan perjalanan dengan tujuan untuk mendapatkan kenikmatan atau kepuasaan dan bisa jadi untuk mengetahui sesuatu. Pariwisata di sisi lain memiliki arti yang luas, yaitu perjalanan dari suatu tempat ke tempat lain, bersifat sementara, dilakukan perorangan maupun kelompok, sebagai usaha mencari keseimbangan atau keserasian dan kebahagiaan dengan lingkungan hidup dalam demensi sosial, budaya, alam dan ilmu (Spillane,2001).

Berdasarkan pengertiannya pariwisata itu mempunyai ciri-ciri (1) pelaku (individu atau kelompok); (2) yang melakukan perjalanan; (3) bersifat sementara; (4) untuk mencari kebahagian, kepuasaan atau kenikmatan. Menurut Hasan (2009), Industri pariwisata adalah keseluruhan rangkaian usaha menjual barang dan jasa yang diperlukan wisatawan, selama ia melakukan perjalanan wisata sampai 
kembali ketempat asalnya. Pariwisata sebagai industri di sini dapat dipahami dengan memberikan gambaran mengenai komponen-komponen kepariwisataan tersebut tidak dapat berdiri sendiri, namun merupakan rangkaian jasa yang saling kait mengkait yang dihasilkan industri lain, misalnya: tarian daerah, industri kerajinan, perhotelan, restoran atau rumah makan, angkutan darat, laut dan udara.

\section{Komponen 3A Kawasan Wisata}

Komponen 3A adalah Amenitas, Aksebilitas, dan Atraksi. Ambarwati Kusumaningrum dalam Kusmaya dan Aldini Kaihatu (2017: 235) pada jurnal Sains Terapan Pariwisata, volume 2, nomor 3, menyatakan bahwa ada empat faktor yang menjadi tujuan wisata yaitu Amenitas, merupakan sarana dan prasarana yang mendukung kenyamanan wisatawan pada saat menikmati objek dan daya tarik wisata yang disajikan seperti sarana ibadah, kamar kecil, penerangan, sarana komunikasi, keamanan, pusat oleh-oleh dan cinderamata. Aksebilitas, kemudahan dalam mencapai objek wisata antara lain: kemudahan transportasi, jalan yang layak, jenis kendaraan yang dapat melintas, rambu-rambu lalu lintas yang mengatur kelancaran perjalanan menuju ke objek wisata. Aktraksi, merupakan sesuatu yang dapat dinikmati, dilihat oleh wisatawan selama berada di objek wisata antara lain: panorama alam, peninggalan sejarah, segala atraksi kesenian dan budaya.

\section{Analisis SWOT}

Analisis SWOT bertujuan untuk mengetahui kekuatan, kelemahan, yang memengaruhi kebijkan internal serta peluang dan ancaman yang memengaruhi faktor-faktor eksternal yang tidak bisa dikontrol. Kombinasi antara kekuatan dan kelemahan dengan peluang dan ancaman dilihat dari suatu matriks yang dikenal dengan istilah SWOT.

\section{METODE PENELITIAN}

Penelitian ini merupakan penelitian deskriptif (descriptive research) atau eksplanatory yakni penelitian terhadap masalah-masalah berupa fakta-fakta saat ini dari suatu populasi. Tujuan penelitian deskriptif untuk menguji hipotesis atau menjawab pertanyaan yang berkaitan dengan status sekarang (current status) dari subyek yang diteliti. Tipe penelitian deskriptif ini meliputi penilaian sikap atau pendapat terhadap individu, organisasi, keadaan ataupun prosedur (Indriantoro dan Supomo, 1999).

\section{Teknik Pengumpulan Data}

Agar memperoleh gambaran potensi objek wisata rempah-rempah kota Ternate di Kecamatan Ternate Tengah Kelurahan Tongole, maka peneliti menggunakan metode observasi (pengamatan), wawancara (interview), dokumentasi dan kajian pustaka.

\section{Pengambilan Populasi dan Sampel}

Populasi adalah wilayah yang terdiri atas objek wisata atau subjek yang mempunyai kualitas dan karakteristik dalam hal ini objek wisata dan bendabenda alam yang mengandung unsur nilai pariwisata. Sebagaimana menurut Sugiyono (2011: 80) bahwa populasi adalah wilayah generalisasi yang terdiri atas objek/subjek yang mempunyai kualitas dan karakteristik tertentu yang ditetapkan oleh peneliti untuk dipelajari dan kemudian ditarik kesimpulan. Populasi bukan hanya orang, tetapi juga obyek dan benda-benda alam yang lain. Populasi juga bukan sekedar jumlah yang ada pada obyek/subyek yang 
dipelajari, tetapi meliputi seluruh karakteristik/sifat yang dimiliki oleh subyek atau obyek itu.

\section{Sampel}

Sampel menurut Sugiyono (2011: 81) bahwa Sampel adalah bagian dari jumlah dan karakteristik yang dimiliki oleh populasi. Bila populasi besar, dan peneliti tidak mungkin mempelajari semua yang ada pada pupulasi, misalnya karena keterbatasan dana, tenaga, dan waktu, maka peneliti dapat menggunakan sampel yang diambil dari populasi itu. Apa yang dipelajari dari sampel itu, kesimpulannya akan dapat diberlakukan untuk populasi. Dengan demikian maka sampel yang diambil dari suatu populasi harus benar-benar mewakili.

\section{Teknik Sampling}

Teknik sampling adalah teknik pengambilan sampel. Didalam menentukan sampel pada suatau penelitian, terdapat bermacam teknik sampling. Pada penelitian ini digunakan teknik sampling nonprobability sampling yakni teknik pengambilan sampel yang tidak memberi peluang/kesempatan sama bagi setiap unsur atau anggota populasi untuk dipilih menjadi sampel. Dalam hal ini teknik sampling yang digunakan adalah teknik sampling Insidental yakni teknik penentuan sampel berdasarkan kebetulan, yaitu siapa saja yang secara kebetulan bertemu dengan peneliti dapat digunakan sebagai sampel, bila dipandang orang yang kebetulan ditemui itu cocok sebagai sumber data. (Sugiyono, 2011:85).

HASIL DAN PEMBAHASAN

Analisis Komponen 3A (Aksesbilitas, Amenitas, Atraksi)

Aksesbilitas

\section{Analisis Data}

Analisis data dalam penelitian ini menggunakan analisis data komponen 3A (Amenitas, Aksebilitas dan Atraksi) serta Analisi SOWT (kekuatan, kelemahan, peluang dan ancaman). Oleh karena itu data diolah dalam deskriptif kualitatif dilakukan sejak pada saat pengumpulan data berlangsung sampai selesai pengumpulan data dalam periode tertentu. Miles and Huberman (dalam Sugiyono, 2011:246), mengemukakan bahwa aktifitas dalam analisis data kualitatif dilakukan secara interaktif dan berlangsung secara terus menerus sampai tuntas, sehingga datanya sudah jenuh. Aktifitas dalam analisis data, yaitu reduksi data (data reduction), penyajian data (data display), dan gambaran kesimpulan (conclusion drawing/verification).

\section{Uji Kredibilitas}

Uji kredibilitas data atau kepercayaan terhadap data yang di dapat dilapangan. Penelitian akan melakukan perpanjangan pengamatan, peningkatan ketekunan dalam penelitian, triangualsi, diskusi dengan teman sejawat, analisis kasus negatif, dan membercheck. Menurut Sugiono, (2011: 270) bahwa uji keabsahan data dalam penelitian kualitatif meliputi uji credibility (validityas interbal), transferability (validitas eksternal),dependability, dan confirmability. Oleh karena itu, uji kredibilitas data dalam penelitian ini akan melakukan penambahan observasi mendalam, wawancara mendalam, serta Focus Group Discussion (FDG).

Aksesbilitas merupakan kemudahan dalam mencapai objek wisata seperti kemudahan transportasi, jalan yang layak, jenis kenderaan yang 
dapat melintas, rambu-rambu lalu lintas yang mengatur kelancaran perjalanan menuju objek wisata.

Aksesbilitas untuk dapat menikmati objek wisata cengkih afo cukup mudah hanya menggunakan jenis alat transportasi pribadi atau umum seperti kenderaan roda dua atau empat. Akses jalan menuju ke objek wisata cengkih afo sangat baik sampai pada

Akses untuk masuk ke objek wisata harus melalui puluhan anak tangga yang dibuat dari semen. Gapura tempat parkiran. Rambu-rambu lalulintas yang mengatur kelancaran perjalanan menuju objek wisata cengkih afo cukup tersedia dengan beberapa petunjuk yang dibuat oleh salah satu organisasi kemahasiswaan sedangkan pemerintah dan masyarakat pengelola belum menempatkan rambu-rambu lalulintas kenderaan untuk akses masuk ke area parkir.

pintu masuk ke objek wisata di tulis dengan menggunakan bahasa lokal Ternate yaitu "selamat si ni kado".

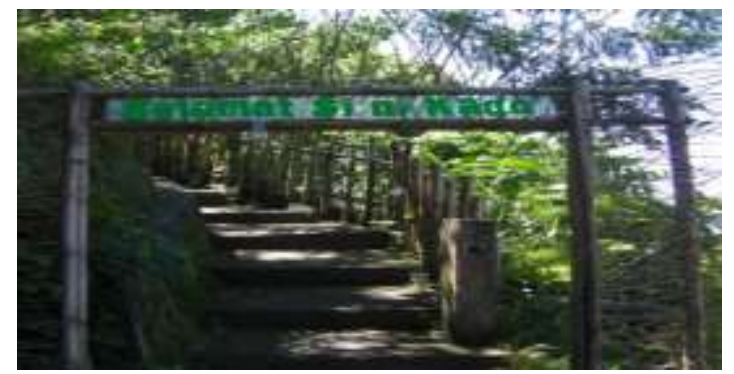

Gambar 2. Jalan Menuju Objek Wisata Cengkeh afo 3

Sumber: Dok. Peneliti 2019

Akses pintu masuk ke Cengkih afo tiga tersebut sangat original karena dihiasi dengan ratusan bambu yang memagarinya. Suasana terdengar seakan disambut musik bambu karena bambubambu saling bersentuhan ketika angin meniupnya. Kemudian, aksesbilitas

\section{Amenitas}

Amenitas merupakan sarana dan prasarana yang mendukung kenyamanan wisatawan pada saat menikmati objek dan daya tarik wisata yang disajikan seperti: sarana ibadah, kamar kecil, penerangan, sarana komunikasi,

Cinderamata yang ada di objek wisata cengkih afo dapat dinikmati akselerasi yang diresmikan oleh Bapak walikota Ternate Dr. H. Burhan Abdurahman, SH.,MM yakni rumah tempat parkir kenderaan sangat memadai seperti tampak pada gambar berikut.

Aksesbilitas lahan parkir di objek wisata Cengkeh afo cukup baik. Lahan parkir merupakan sarana pendukung objek wisata.

keamanan, pusat oleh-oleh dan cinderamata. Sarana dan prasarana yang terdapat di objek wisata cengkih afo dapat dinikmati dengan panorama cengkih seperti tersedia sarana ibadah dari rumah bambu, sarana kamar kecil, penerang, keamanan dan cinderamata.

akselerasi zona IKM kepariwisataan (AZIK) pada hari sabtu tanggal 10 November tahun 2018. AZIK merupakan tempat souvenir oleh-oleh atau cinderatama khas lokal dalam 
Jurnal Penelitian Humano, Vol. 10 No. 1 Edisi Juni 2019

bentuk kerajinan-kerajinan tangan masyarakat sekitar objek wisata. AZIK berada disekitar objek wisata cengkih

afo sekitar 50 meter dari tempat objek cengkih afo 3.

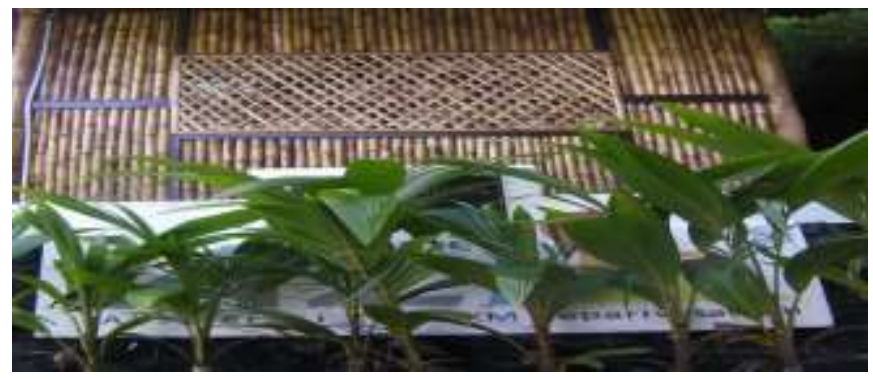

Gambar 5. Akselerasi zona IKM kepariwisataan (AZIK)

Sumber: Dok. Peneliti 2019

\section{Atraksi}

Atraksi merupakan sesuatu yang dapat dinikmati, dlihat oleh wisatawan selama berada di objek wisata seperti panorama alam, peninggalan sejarah, segala atraksi kesenian dan budaya. Melihat dari letak geografis Destinasi wisata Cengkih afo di kelurahan Tongole berada pada ketinggian dan berbukit-bukit. Objek wisata Cengkih afo menarik dan penuh sejarah untuk dikunjungi. Destinasi wisata Cengkih Afo diketahui masyarakat Tongole sekitar sebagai cengkih tertua di Maluku Utara. Lokasi destinasi cengkeh Afo ini sekitar 6 kilometer dari pusat kota Ternate. Objek wisata Cengkih Afo berada pada ketinggian 800 meter, sekitar 2 kilometer dari pos pengamatan Gunung Api Gamalama, tepatnya di kawasan ekowisata air tege-tege atau air menetes, Kecamatan Ternate Tengah Kota Ternate.

Cengkih afo diambil dari perpaduan bahasa Indonesia dan Ternate. Bahasa Ternate cengkih yakni "buwa lawa"1, dan "afo"2 bermakna

1 "sejenis pohon yang besar". Cengkih afo oleh masyarakat sekitar menyakini sebagai Cengkih tertua di Ternate bahkan "di dunia". Cengkih afo menurut masyarakat kelurahan Tongole adalah peninggalan para leluhur yang disimpan di pohon-pohon afo pada saat bangsa penjajah Belanda menghanguskan dan penebangan besar-besaran tanaman Cengkih di Ternate pada tahun 17221890 yang dikenal dengan sebutan ekstirpasi.

Ada pula yang mengatakan bahwa kata "afo" berasal dari nama keluarga Alfalat, yang berhasil menyelamatkan sebuah pohon cengkih pada saat bangsa penjajah menghanguskan semua tanaman cengkih di Ternate untuk mengambil alih monopoli perdagangan cengkih di Ternate pada tahun 1722-1890. Menurut Deinum dalam diskusi Nani Jafar bahwa cengkeh hakekatnya di Ternate, Tidore, dan Makean berasal dari pulau Halmahera. Menurutnya bahwa cengkeh yang ada di Ternate, Tidore dan Makean di bawah oleh burung dari pulau

2 afo bahasa Ternate merujuk pada sejenis pohon dengan karakteristik daun lebar warnah hijau dengan pohon warnah coklat. 
Halmahera yang di buang melalui kotorannya.

Sejarawan JJ Rizal berpendapat bahwa keberadaan pohon cengkih afo ini adalah artefak dari era kejatuhan masa jaya cengkih. JJ Rizal mengatakan, memang tidak ada catatan sejarah khusus yang menceritakan asal muasal pohon cengkih. Diperkirakan pohon cengkih sudah ada jauh sebelum pohon cengkih afo generasi pertama. Ini bisa dilihat dari pedagang Cina dan Arab yang telah memperdagangkan komoditas cengkih ini hingga ke Eropa. Bahasa lokal, cengkih disebut dengan gau medi 3 atau "pohon pedas". Cengkih awalnya tidak dikenal oleh masyarakat Ternate, namun diperkenalkan oleh orang-orang Cina. Kata "cengkih" berasal dari bahasa Cina, "zeng qi $a$ ". Ini sejalan dengan kisah Kaisar Han pada abad ke-IV yang memerintahkan semua tamu kerajaan untuk mengunyah cengkih sebelum bertamu agar mulutnya wangi. Cengkih saat itu adalah simbol kebangsawanan dan prestise, selain fungsi biologisnya sebagai pewangi, penyedap, dan pengawet. Catatan sejarah lain, pada tahun 1500 SM pada era Babilonia, ditemukan sebuah bejana berisi cengkih dalam sebuah rumah. Ini menunjukkan betapa tuanya jalur perdagangan cengkih. Sejarawan JJ Rizal juga menyebut, keberadaan cengkih afo membuktikan, nenek moyang cengkih berasal dari daerah Maluku Utara, satu di antaranya di Ternate. Ia pun membenarkan, tidak ada penjelasan pasti kapan pertama kali cengkih ditemukan. Catatan sejarah menjelaskan, dulu masyarakat setempat justru tidak mengenal cengkih sebelum kedatangan

3 gau medi bahasa Ternate merujuk pada pohon Cengkih para pedagang-pedagang dari China, tidak jelas kapan pertama distribusi cengkih ini mulai dilakukan. Hanya saja, sekitar lima tahun sebelum masehi, ada budaya di China dimana tingkat kebangsawanan seseorang di sana dilihat dari berapa banyak dia mengunyah cengkih. Bahkan di Babilonia, pada 1500 SM ditemukan bejana yang satu di antara isinya adalah cengkih. Jadi, jaringan cengkih ini sudah berjalan dalam periode yang sangat panjang jauh sebelum kedatangan bangsa Portugis di Ternate. Masih pendapat JJ Rizal bahwa ketenaran cengkih dari Maluku Utara akhirnya menimbulkan berbagai dampak luar biasa, termasuk menyebabkan berdirinya Indonesia. Dari pencarian cengkih menimbulkan terbentuknya tata dunia. Orang-orang Eropa berlomba mencari cengkih ke sini dan dalam perjalanan mereka menemukan tempattempat baru.

Destinasi Cengkeh afo terbagi tiga lokasi destinasi wisata, yang disekitarnya ditumbuhi banyak pohon cengkih masyarakat. Pada lokasi destinasi wisata Cengkih afo generasi pertama diperkirakan berusia lebih dari 400 tahun atau sekitar 416 tahun. Cengkeh afo pertama sudah roboh pada tahun 2000, perkiraan pohon Cengkih afo generasi pertama ini mempunyai ketinggian pohon $36,6 \mathrm{~m}$, diameter 1,98 meter, dan panen permusim mencapai $600 \mathrm{~kg}$. Lokasi destinasi wisata Cengkeh afo kedua sampai pada penelitian ini dilaksanakan tersisa puing-puingnya saja karena sudah roboh pada tahun 2019 karena tiupan angin kencang. Cengkih afo generasi kedua diperkirakan berusia 250 tahun, letaknya 600 meter dari permukaan laut, untuk mencapai kelokasi destinasi cengkeh afo generasi 
kedua ini harus melewati 69 anak tangga.

Pada lokasi destinasi cengkih afo generasi pertama dan kedua atau dikenal dengan cengkih afo 1 dan afo 2 oleh masyarakat sekitar tidak lagi menjadikan objek wisata, terlihat disekitar lokasi dimana tempat hidup kedua cengkih itu, tidak terurus dengan baik, dan pemerintah pun tidak lagi merawat dan mengelola kedua tempat itu menjadi objek wisata yang menarik. Terlihat disekitar objek cengkih afo 1 dan afo 2 tidak ada satu bangunan pemerintah.

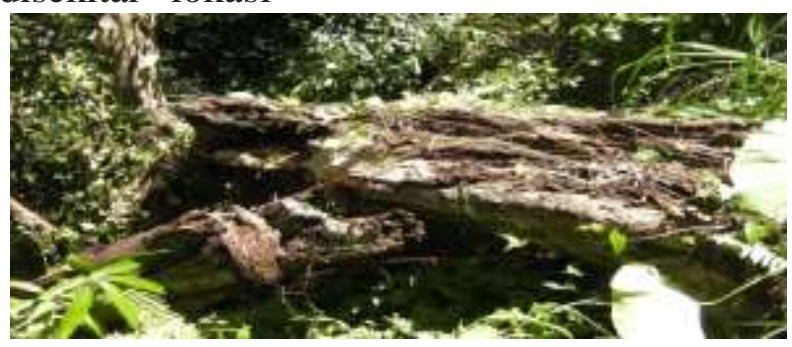

Gambar 6. Cengkeh afo generasi kedua yang sudah roboh Sumber: Dok. Peneliti 2019.

Selanjutnya, Cengkih afo generasi ketiga usia diperkirakan 200 tahun, tumbuh di lokasi yang tidak terlalu berjauhan di kelurahan Tongole, untuk mencapi kelokasi ini harus melewati puluhan anak tangga sekita 38 anak tangga. Cengkih afo generasi ketiga ini masih tumbuh namun beberapa dahannya patah akibat terpaan angin kencang. Cengkeh afo generasi ketiga ini oleh masyarakat masih dikembangkan menjadi objek wisata yang menarik untuk dikunjungi, ini terlihat disekitar tumbuhan Cengkih afo 3 ini terdapat beberapa tempat santai berupa rumahrumah santai yang unik.
Destinasi cengkih afo 3 ini dikelola oleh 44 kepala keluarga dan pemuda kelurahan Tongole yang terhimpun dalam komunitas Cengkih afo dengan sebutan Cengkih afo dan Gamalama Spices Community (CAGS) sebagai tempat destinasi wisata rempahrempah. Komunitas ini terbentuk dengan menyiapkan konsep awal paket kunjungan yang menarik. Ide komunitas ini mendorong masyarakat sekitar agar membentuk dan melestarikan pohon Cengkih afo, dan destinasi cengkih afo untuk bisa menjadi tujuan wisata yang layak dikunjungi oleh wisatawan.

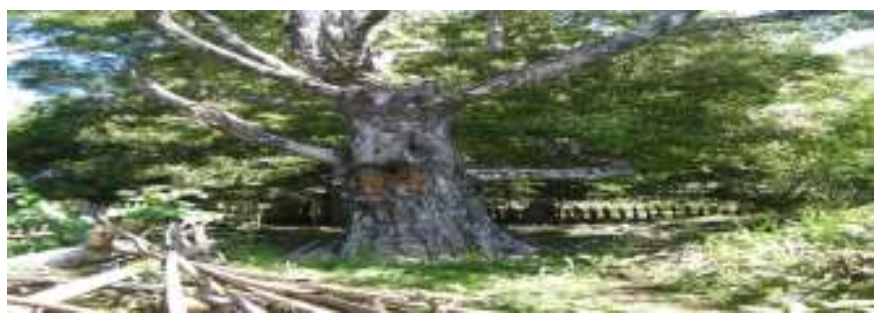

Gambar 5. Cengkeh afo generasi ketiga

Sumber: Dok. Peneliti 2019.

Kawasan Destinasi wisata kuskus atau bahasa Ternate di sebut cengkih afo juga terdapat habitat hewan "kuso". Hewan ini muncul pada malam 
hari atau pagi dini hari disekitar pohon cengkih dan kayu sekitar lokasi destinasi wisata cengkih afo. Destinasi wisata Cengkeh afo sudah lama dikenal masyarakat sekitar Ternate. Namun, baru

\section{Analisis dan Skor Lingkungan Internal dan Eksternal \\ Pengkajian pengembangan}

destinasi Cengkeh afo dapat dilakukan dengan analisis SWOT mulai dari analisis faktor internal atau internal factor analysis strategic (IFAS) dan faktor eksternal atau eksternal factor analysis strategic (EFAS). Analisis SWOT pada faktor-faktor tersebut dapat menentukan nilai kekuatan, kelemahan, peluang dan ancaman. Faktor-faktor kekuatan (strengths) dan kelemahan (weakness) seperti nilai daya tarik destinasi cengkeh afo seperti kealamiahan, keanekaragaman flora dan fauna, kondisi jalan, sarana transportasi umum, kondisi kejernihan air, toilet, petunjuk jalan/sign system, kebersihan, tempat pembuangan sampah, area parkir, penerangan jalan, souvenir khas, warung sekitar DTW, agen perjalanan, tempat

\section{Analisis Faktor Internal dan Eksternal}

Penilaian lingkungan internal dan ekternal potensi wisata cengkeh afo digunakan pedoman identifikasi pemeringkatan diberikan dengan Analisis internal dan ekternal objek wisata cengkeh afo dapat dilihat pada diagram batang sebagai berikut: dikembangkan setelah adanya kelompok atau komunitas Cengkih afo dan Gamalama Spices Community (CAGS) pada tahun 2018.

bersantai, atraksi hiburan, internet, jaringan telpon, kondisi masjid, ATM, hotel/penginapan, pos kesehatan, asuransi tiket, TIC serta lokasi strategis. Sedangkan, faktor-faktor peluang (Opportunities) dan ancaman (Threats), seperti kondisi pesaing daya tarik wisata, kebijakan pemerintah, karakteristik peran serta masyarakat.

Untuk menilai lingkungan internal potensi kawasan Cengkih afo digunakan identifikasi dan definisi variabel dalam tabel, pemeringkatan diberikan dengan menilai jawaban pilihan dari empat alternatif yakni sangat buruk, buruk, baik dan sangat baik. Hasil penelitian menunjukkan masing-masing responden memberikan nilai yang bervariasi. Perhitungan nilai peringkat (rating) responden didasarkan pada nilai rata-rata dari seluruh responden.

menjawab pilihan melalui kuesioner dengan menjawab pilihan dari empat alternati yaitu ketersedian infrastuktur, daya tarik, kondisi dan situasi serta citra bentuk yang ada di objek wisata Cengkeh afo. 
Jurnal Penelitian Humano, Vol. 10 No. 1 Edisi Juni 2019

Gambar 6. Penilaian Faktor Internal dan eksternal Objek wisata Cengkeh afo.

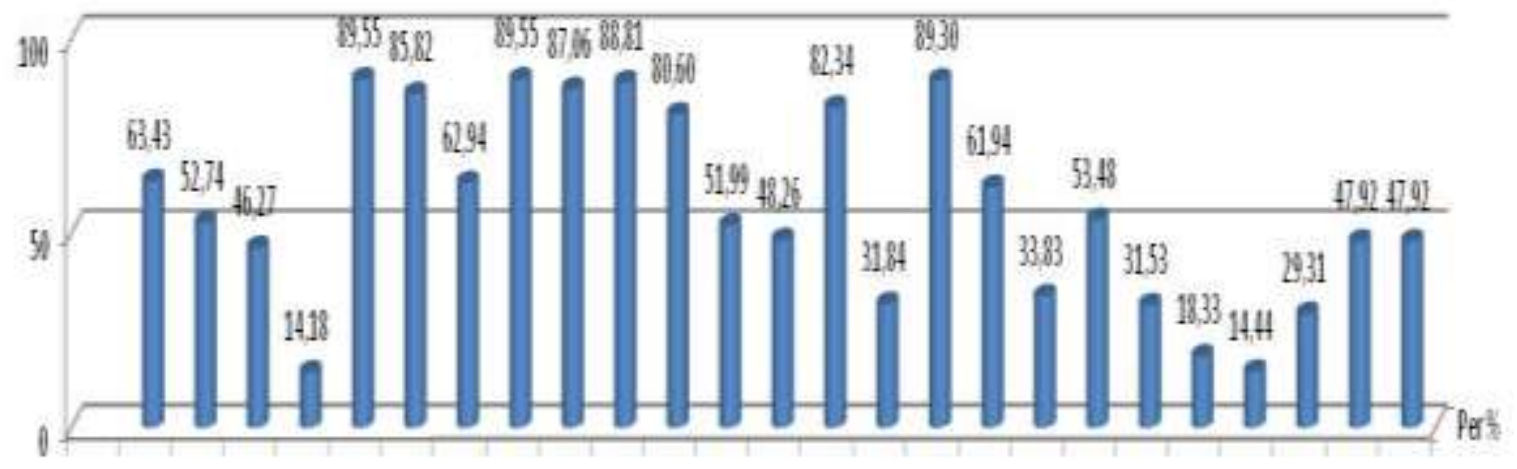

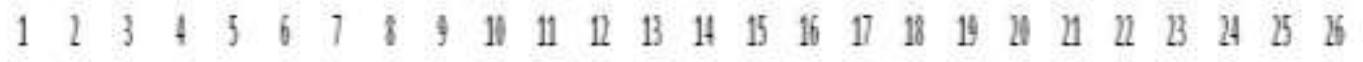

Sumber: Data peneliti

Diagram batang di atas menunjukan bahwa faktor internal dan ekternal pada objek wisata cengkeh afo dari penilaian 26 responden menemukan sangat variatif. Pada responden nomor 1 sampai 26 mempunyai penilaian terhadap objek wisata terendah $14,18 \%$ sampai pada tertinggi $89,55 \%$, atau keseluruhan $867,22 \%$.

\section{PENUTUP}

\section{Simpulan}

Penelitian ini menyimpulkan bahwa aksesbilitas, amenitas dan atraksi objek wisata cengkeh afo sangat baik dan mudah dikunjungi. Penilaian dan strategi cengkeh afo dari responden yang di dapat berada pada $14,18 \%$ sampai pada tertinggi $89,55 \%$, atau berada pada posisi strategi kuadrat kuat atau total keseluruhan 867,22\%.

\section{DAFTAR PUSTAKA}

Deddy Prasetya. Pengembangan Potensi Pariwisata Kabupaten Sumenep, Madura Jawa Timur (Studi Kasus Pantai Lombang). Jurnal Politik Muda,Vol 3, No 3 AgustusDesember 2014, hlm 412-421.

Gugun Gunardi. Identifikasi Potensi Kawasan Wisata Kali Pasir, Kota
Tagerang. Jurnal Planesa, Vol 1, No 1, Mei 2016.

Ismuhadi, Heru W, dkk. .Pengembangan Potensi

Pariwisata Dalam Perspektif Reinventing Government. Jurnal Administrasi Publik (JAP), Vol 1 , No 6, hal 1168-1173

Sugiyono.2010. Metode Penelitian

Kualitatif, Kuantitatif dan R \& B. Bandung: Alfabeta,CV

Porter, ME.1980.Competitive Strategy:

Techniques for Analyzing Inndustries and

Competitiors, NY: The Free Press.

Spillane, James J.2001. Ekonomi Pariwisata, Yogyakarta:Kanisius.

Spillane, James J. 1994. Ekonomi Pariwisata: Sejarah dan Prospeknya. Yoyakarta, 